\title{
THE DEVELOPMENT OF INTERNATIONAL AIR FREIGHT
}

\author{
RAYMond A. NORDEN*
}

Advent of the long-range airplane which could lift a substantial payload presented the first opportunity in more than one hundred years to accelerate the delivery of goods across water barriers. Modern steam freighters carrying the bulk of the world's goods move little faster than the clipper sailing ships of our early American days. The impact of air transportation on international trade has been and will be, therefore, far more profound than it is on the domestic scene where between the wagon train and the airplane we had the railroad and the truck.

International air freight reduces to about one-twentieth the time consumed in spanning the oceans. Speed is, so to speak, the raison d'être of air freight; its concomitants are the elements which make shipping of many products by air at higher rates more economical than shipping by ocean freighter at lower rates.

But a caution on speed of itself is necessary at the outset. Ever increasing speed, however desirable in passenger and mail carriage, must not become an obsession in freight. The economic justification for international air freight accrues from a combination of speed, direct flight to destination, and personal attention to the goods carried. From each of these, or a combination, stem the concrete economic gains.

Compression of time in transportation has preoccupied man since the exchange of goods began, because any kind of property in transit is idle, worthless, and profitconsuming. The astute manufacturer, importer, or exporter will always think of distances as time, and not miles.

The logistically minded men of the Air Transport Command had such lessons ground into them by the rough edge of war. Major General William Tunner, of Military Air Transport Command and genius of the Berlin Airlift, recently set forth graphically what is involved in loss by a routine replacement of $r, 000$ men in the Panama Canal Zone. To carry I,000 men to Panama by ship and bring $x, 000$ out, he said, involved a loss of 34,000 man-days. Movement of the same number by airplane cost 4,000 man-days. The General invited his listeners, members of the Commerce and Industry Association of New York, to consider what they could pick up "free" by changing their means of transportation.

Delivery of goods in a day or two instead of weeks means drastic shortening of the profitless transit period, whether the goods be merchandise or machinery; it means eliminating the need for large inventories, hence less capital tie-up; it means less warehousing, faster re-orders, and the opportunity to meet the peak demand. It cuts the risks of encountering exchange fluctuations, and speeds collections.

Direct flight means over-flying of congested ports and bringing inland cities to

- President, Seaboard \& Western Airlines, Inc. 
tidewater; elimination of multiple handling and transshipment and the costs therefor; and access to markets hitherto untapped.

Personal handling, plus the very nature of the transportation equipment, which is itself a relatively delicate instrument, means virtual elimination of pilferage and damage from shock, pressure, and moisture, substantially lower insurance, lighter, cheaper crating, and certainty of delivery.

Wider acceptance of international air freight will come with wider knowledge of its economics and with lower rates. Lower rates will come with lower costs. Lower costs will come from growing experience, and with the development of an airplane strictly designed for freight carriage and affording increased payload. Already, the fifty-ton payload airplane is in sight, although still in the proving stage.

I

In this discussion of international air freight, any egocentric element with relation to my company's activities will have to be pardoned as inevitable, because it is the only trans-oceanic airline which is truly devoted to the freight business. It carried $3^{6}$ per cent of all the tonnage moved in and out of the United States by it and the three certificated North Atlantic carriers in 1948 , yet it operated only 4 per cent of all the flights which moved this property.

This writer began studies of air freight potentials and costs in 1937 while engaged in the aviation insurance business, but up to the outbreak of war determined only that (a) costs with current types of aircraft would be too high, and (b) there were no aircraft available anyway.

It would seem that man makes his most progressive strides-at least in the fields of transportation and some sciences-under the drive of war's necessities. The I9r4-18 conflict produced a forced growth of automotive transportation; the famous French seventy-fives went into action in IgI4 with horses, but came out in IgI8 motorized. The result of that war was the trucking industry of the Twenties.

The second war was really a World War, fought in two hemispheres and not even circumscribed by the Arctic and Antartic parallels. Transportation of men and matériel over vast distances, wastes of ocean and desert, and towering peaks, was vital. Again, necessity was the mother of invention, and strategic airlift was born. At its peak of operations, the Air Transport Command alone flew 3,000 aircraft, manned, maintained, and directed by a quarter-million men, and carried I70 million ton miles a month-the equivalent of 2,000 freight cars moving capacity loads from New York to San Francisco. Over the Himalayas, in all kinds of weather, an odd assortment of aircraft lifted daily from India to China, 5,000 tons of trucks and ammunition, bombs and gasoline, howitzers, mules, and road-building machinery.

The men who did these jobs were indicating the possibilities of the third dimension. The Wright brothers gave man wings. The impelling necessities of war gave wings to the hitherto earth-bound weapons of destruction, and indicated what 
the air age could be when the firing stopped. For, in the inspired words of Mr. Gill Robb Wilson, aviation pioneer and columnist of the New York Herald-Tribune:

If this is the Air Age, it is so because the airplane can move the merchandise of civilization and not because it can haul a few people around in a hurry. If this is the Air Age, it is so because air transport can lick the Hump and the Soviet blockade and the gray waters of the North Atlantic and the earthquakes of South America and the isolation of Alaska.

Men who not only flew the airplanes of the ATC and the Naval Air Transport Service but gained intimate knowledge of engineering, maintenance, safe flying procedures, scheduling, traffic, and handling of personnel, were deep into consideration of air freight long before the last shot was fired. The small group, for instance, which conceived and founded my company, met during war service with ATC, discussed the possibilities of the post-war scene, drifted apart under the exigencies of war, corresponded, and then got together after separation from the service. Sitting down together, they found that five men, mostly in their late twenties, had a combined total of affliation with aviation of more than forty-five years. Two of the group qualified in safety of aircraft operation (one had written and supervised the Flysafe Project for the India-China Division and then adapted it to North Atlantic operations); three had extensive knowledge of aircraft maintenance; two of aviation insurance; and two had experience with commercial scheduled airlines.

Importantly, too, scattered as they had been through the theatres of war, they had intimate knowledge of the capacities and personalities of innumerable pilots, and of operations, traffic and engineering personnel. It was a great pool from which to draw flight and ground people for an air freight venture.

In the ensuing studies, the matter of operational costs was given extreme care. As a result of war experience and post-war calculations, before ever a plane was flown it was as though a period of trial and error had been undergone. Subsequent operation costs, in fact, came within a couple of cents per revenue mile of those estimated more than a year before the first flight was made. This, plus the fact that total indirect costs have been kept down to a shade over 20 per cent of total direct flying operations, is mentioned chiefly because cost consciousness is clearly a prerequisite to the movement of bulk freight by air.

As to international air freight potential in the planning days, there were no yardsticks. No real effort had ever been made to explore the field of air freight as contrasted with air express, but a survey of the latter was heartening for two main reasons. First, it showed almost complete lack of air freight facilities which would make bulk shipment possible and dent the North Atlantic slow boat tradition. Second, shippers of all types were unanimous in stating that air express rates ruled out all but "must" items; restrictions on weight and size were totally inadequate; air shipping space was hard to get; and when it was available it was unreliable because of the practice of offloading in favor of passengers. 
Clearly, then, what was needed was a facility devoted to air freight alone; conducted with the highest maintenance and operating standards, but with the strictest austerity; offering capacity for bulk shipment; and dedicated to meeting the shipper's needs.

Here was the opportunity for those who had flown supplies to fighting men the world over; had shifted a Chinese Army and its paraphernalia from Western China to Shanghai; and had operated, maintained, and directed the logistical use of hundreds of aircraft. It was extremely unilkely that any of them could have quoted Tennyson's purple verse about "the argosy of the skies," but the dream was there nevertheless.

\section{II}

In international air freight, traffic, operations, and sales must be geared to the single-minded job of giving the shipper what he is paying for-speed of delivery. Twenty-four hour flight to Europe means nothing if documentation of shipping papers, ground handling, government clearances, and loading are not expedited.

Normal procedure on air express involves notification by mail following arrival of the goods at the airport. That isn't good enough for air freight. It must be done by phone or wire, or the airline must have authority to appoint a broker to clear the shipment. Because of the small number of shipments per aircraft involved in a bulk air freight operation, this sort of tactic is facilitated, and it is possible much of the time to truck the goods to their ultimate destination on the day of arrival at the airport.

Conversely, outward bound shipments must waste no time on the ground. Perhaps an outstanding instance of flexibility, so essential to the operation, may be cited. Last July, the S.S. Seven Seas was disabled in London for want of an 8,500 pound rotor for its diesel engines. The cable notifying the ship's operator was received in New York at I6:00 DST. The piece was located on Staten Island at I6:20, space booked at $16: 35$, and loading at Staten Island begun at $17: 30$. The rotor reached the New York International Airport at 21:00, and the airplane departed at 23:32, reaching London the following evening. Such a performance should be routine with the international air freighter.

The traffic department must apply itself to close study of the airplane's capacity in relation to weight, dimensions, floor loading, support, tie-down, containment, and attention en route. Specialized attention must be given to load engineering, and there should be much experimentation with freight of all the sizes, shapes, and weight that can be made to fit into the $1_{5,000}$ pound payload capacity of a stripped. down $\mathrm{DC}_{-4}$, which is the airplane now available for over-ocean carriage.

The traffic department must be prepared to boggle at nothing. True, it has been our experience over two and a half years that wearing apparel constitutes about 43 per cent of the total business, with substantial percentages of pharmaceuticals, furs, textiles, watches, clocks, cameras, automotive and aircraft parts, castings, boiler 
tubes, etc., making up the greater part of the remaining 57 per cent. But whole aircraft have been offered and accepted; and also Bell helicopters, ship's parts in single units in excess of seven tons, dredging machinery and oil refining machinery up to six tons, race horses, cattle shipments in excess of five and a half tons, small elephants, dogs, snakes, gorillas, leopards, and cages of monkeys. These last animals require particular care en route, especially on such a flight as was made early this year ranging from too degrees Fahrenheit plus in. Singapore to 16 below at Labrador.

The development of international air freight calls for a constant missionary effort, in this country and especially in Europe, to wean the shipping mind away from the boat tradition and acquaint it with the economics of air freight. The Continental mind particularly was not exposed during the war to the knowledge of strategic airlift, and consequently the most elemental education about the capacity of a fourengined airplane must be carried on there if the business is to grow.

Safety is, of course, the prime consideration of the operations division of every airline; Seaboard is no exception, and it is proud of a record in that respect which is second to none in the world among either passenger or freight carriers. The air freight carrier, however, departs from the second chief consideration of the passenger carrier-performance of schedules-and aims for economy of operation consistent with the best possible service to shippers. Aircraft must be routed to achieve the maximum out of every gallon of fuel. Weather and other data must be collated so that aircraft can be routed to provide maximum lift at minimum cost, and while the captain of any flight makes the final decisions, they are based on information sent to him at any and all points.

If I may again use Seaboard as illustrative of the development of the business, flight operations were begun May 1o, 1947, with one DC-4. The present fleet is five $\mathrm{DC}-4$ 's. From the first, they were converted to the carriage of a 15,000 pound payload.

The first eight months (May through December, 1947) produced a total of $1,267,000$ freight ton miles.

The succeeding twelve months of 1948 saw a ton mile carriage of 5,755,000. Thus far this year (1949), to August $3 \mathrm{x}$, the ton mile total is $3,047,000$, making the grand total for twenty-eight months slightly in excess of I0,000,000 freight ton miles.

The true "freight" nature of the carriage may be shown by two comparisons.

Early this year, the Port Authority of New York analyzed the property carriage of twelve passenger airlines operating internationally out of LaGuardia and Idlewild. There were $1, \mathrm{I}_{4} 0$ separate shipments in twenty-four hours, and 94 per cent of them weighed less than roo pounds.

A recent breakdown of Seaboard's monthly carriage showed that 73 per cent of the total weight carried was accounted for by individual shipments of 700 pounds or over; 66 per cent represented shipments of 1,000 pounds or over; 52 per cent represented shipments of over one ton; only 5 per cent of the total weight represented shipments of roo pounds or less. 
This difference in the weight of shipments as carried by Seaboard and as carried by the passenger airlines is of real significance. It shows clearly the bulk nature of air freight; it shows clearly that someone new has come within the field of vision of the airlines-the exporter who ships his quantity order by air instead of merely his samples. For years exporters' samples have traveled to destination by air express, carried in the cargo compartments of passenger airplanes. Now for the first time, a significant volume of bulk goods has been wrested away from the traditional ocean freighter. If this small and yet significant victory is to blossom forth into a truly vast exchange of goods by air to and from all ports of the world, it will be done only through the dogged efforts of those airlines who have faith in the future, singleness of purpose and organization, and airplanes dedicated to the needs of the shipper.

A recent article in Shipping Digest will help illustrate the latter point. The fact that it refers to the B.O.A.C. makes the illustration none the less applicable to most operators of combination passenger-mail-express airplanes. The article stated:

One evening at 6:30, B.O.A.C. received an order to ship one piece weighing $1,885 \mathrm{lbs}$. to Durban, South Africa. The piece of cargo was seven inches too long to fit into a Constellation, so a booking was made on another carrier to fly the cargo to Cairo. ...

It is a splendid example of the truth that the passenger-mail-express carrier is not geared by the nature of its equipment, its operations, or its thinking to fly bulk freight. When an Italian tanker lay disabled at Milan a few months ago for want of a lower stern frame weighing seven and a quarter tons, there was no question of its being "seven inches too long" for Seaboard's Airtrader.

It is perfectly clear that bulk freight cannot be loaded into a $\mathrm{DC}_{-4}$ passenger airplane whose largest door measures a fraction under 38 by 30 inches; or into a Constellation whose largest door measures $4 \mathrm{I}$ by less than 23 inches.

It is quite absurd to talk about conducting international air freight operations with passenger-carrying aircraft flying on schedule. Such scheduled flights mean that the freight shipper must conform to a rigid operation and take a chance that his freight will be loaded piecemeal-if there is any space available at all. To treat freight as a secondary (or is it tertiary?) consideration is definitely not to develop the business.

The trans-Atlantic certificated passenger carriers, arguing diversion, have cited that they are unable to utilize even 50 per cent of the available weight space in their combination planes. But diversion isn't the reason; the non-utilization arises from the fact that the air freight shipper is not interested in the kind of accommodation he gets from operations which:

(I) Limit the type of goods which can be carried by size, weight, shape, and nature.

(2) Cannot accommodate any freight at all during peak periods of passenger travel where there is just about enough space left, after passengers and mail are loaded, to carry a few express packages. 
(3) Cannot guarantee him against off-loading at any point en route, in favor of mail, passengers, and other priority requirements.

Entirely apart from these considerations, the passenger-mail-express carrier lacks the flexibility to develop air freight, which is just not adaptable to passenger schedules. Unused space in a passenger plane can never fill the air freight shipper's requirements because the space bears no relationship to the time and place where the freight demand exists. It is useless to offer the shipper space on a Brussels-bound airplane when he wants to ship to Geneva. And 16,000 ton miles of "space" in the belly compartment of a passenger plane is equally useless if there are two prize bulls to be loaded.

None of this discussion is intended to derogate from the performance of the scheduled passenger carriers as such. It is simply by way of suggesting that "they stick to their lasts," which is the carriage of passengers, mail, and express, unless they are prepared to tackle the international air freight business by getting down to their shirt sleeves and separating it from the plush of the other operations.

The truth is that freight has not been diverted during the past two years on the North Atlantic route from the grandfather airlines. The truth is that if it had not been moved by the all-freight air carrier, it would have moved by ocean shipping. For instance: a New York clothing exporter shipped abroad from October 2x, 1946, through May 5, 1947, by boat 266,571 pounds of merchandise, and by airplane 972 pounds. During the succeeding nine months when an all-freight carrier's services were available, the firm shipped 40,565 by air and 1,37 I by boat.

\section{III}

Seaboard's operations from an equipment point of view are modest; they are gigantic when put against non-existent yardsticks for comparison. This pioneering has proved the need for international air freight service between the United States, Ireland, Great Britain, the western perimeter of Europe, Germany, Switzerland, Italy, Greece, Egypt, and the Middle East. It has proved that a bewildering array of goods will move by air with profit to the carrier and the shipper.

Even with the use of the $\mathrm{DC}_{-4}$, an airplane not specifically designed for air freight, it has been possible to reduce freight rates substantially within two years. Briefly, rates between New York and Brussels, Geneva and Milan, for instance, have been cut from $3^{0}$ to $3^{6}$ per cent. The rate to and from Athens for a 5, I20-mile haul is currently comparable to a rate two years ago for a 3,979-mile haul to Geneva. Month by month, specific commodity rates swell the already substantial list between fifteen cities of Europe and the Middle East and the United States; insurance and excess valuation rates also have been comparably reduced.

The need for such an international air freight operation can best be met by the all-freight carrier, unsubsidized, operating on a demand basis rather than on a rigid schedule, and affording service to a number of cities in specific areas rather than one city on a specific route. This latter condition is necessary in order to enable 
the carrier to serve the bulk shipper at the most convenient shipping point; to provide the carrier with a sufficient trade area from which to draw freight moving in both directions regardless of seasonal or other fluctuations; and to provide alternate cities and airports so that the hazards of spoilage in the case of perishable cargo may be minimized.

It is essential that the fundamental difference between air transportation of property and of persons be recognized in considering the above. The property carrier must be permitted to fly between specific areas or terminals on the most direct practical route on which weather is flyable, if he is to render the most valuable, dependable, and economic service. The demand basis is especially important if the carrier is to be sufficiently flexible to meet the needs of air freight shippers.

\section{IV}

Assuming the design and construction of a freight airplane with a high payload and reasonable operating costs and assuming the acquisition of those airplanes in such substantial numbers as to constitute a Merchant Marine of the Air, the impact upon world commerce and marketing practices will be tremendous.

To the present highly developed areas of the world would be given a means of transportation which would totally revolutionize marketing and distribution thinking. To the undeveloped areas, potential untapped markets, would be afforded the boon of direct flight and close contact with the industrial world. Direct fight would be especially important to those whose internal transport is primitive and slow. To all inland points the world over would be brought the advantages of tide-water.

The race in commerce has always been to the swift. It will be truer still as this air age progresses. Availability of international transport in the air will attract volume, as it always has in other fields of transportation. To date, volume has been retarded because adequate air transport for goods has been generally unavailable.

But as it becomes available through the operation of large numbers of freight aircraft, a substantial section of industry and commerce will become impatient with slow water-borne transport. It really doesn't matter who takes the loss entailed by idleness of merchandise and machinery in transit, the loss is there; it is a loss to society which cannot be tolerated when the means are available to reduce it to a minimum.

Then, too, ocean surface shipping was tolerable in the days of slow communication of information. Once upon a time, we didn't know what was going on industrially or otherwise in England or France or Greece until a ship arrived with letters and newspapers to tell us about it. Today, communication has the speed of light; it is unthinkable that we should cling to the transit speeds of a century ago when we know instantly what $X$ has 3,000 miles away which we need, or $X$ knows what we have that he needs.

The efficiency of international air freight in avoiding loss entailed by slow transport is illustrated often in these days of so-called regression, alias the buyer's market. For instance: 
This mid-summer a New York importer wanted 30,000 pounds of fine woolens and worsteds for men's and women's wear from Europe to meet manufacturers' demands for material to make garments for the fall trade. Surface shipping could not meet the need; fabric and style had been settled upon, the market calculated, and the peak determined. The goods must fly.

If we accept the passenger airlines' descriptions of their own "cargo" operations, the 30,000 pounds, factory-prepared in bales of $15^{\circ}$ pounds each, probably would have moved at the rate of a half dozen bales or less per flight, not to mention the chance of their being off-loaded at Shannon or Gander. Conceivably, thirty to forty flights would have been required to move the shipment. Flown by passenger carrier, the goods would have dribbled into New York; the manufacturer would have sweated out the question of whether he would ever get his share in time for processing; and the importer would have had a total of about $\$ 320,000$ purchase price, customs duties, and carriage cost tied up for an unknown length of time.

Being an astute fellow, the importer had them flown by an all-freight carrier in three sections, along with several thousand pounds of other freight, in less than a week. Musing on the operation at Idlewild when the second section arrived and the third was in the offing, he said: "The money will be in the bank on Thursday."

This illustration brings into focus all the dire things that can happen to an importer or manufacturer awaiting merchandise from a point thousands of miles distant-the passing of the peak demand; tie-up of capital; the necessity for large inventories and the threat of forced, ruinous sales if the demand passes; warehousing and transshipment costs; and the losses from pilferage and damage.

In export to Europe, air freight can justify itself by direct flight to destination alone when it is remembered that the Department of Agriculture estimates, in regard to American food shipments to that continent, that freight travels about eight miles a day to its destination after it reaches a European port. This appalling fact was revealed when Secretary Brannan was asked to explain why potatoes were being destroyed in this country and not sent to Europe. He replied simply that if we could find the refrigerated ships to carry them, we would find the European docks too congested to receive them, and after that they would rot while moving at a snail's pace in European rolling stock.

\section{$\mathrm{V}$}

National defense has a vital stake in air freight development. This is shown by the oft-repeated statements of such as Major Generals Kuter, Tunner, Knerr, and others, that the Military Air Transport Service cannot possibly acquire and maintain in peace the strategic airlift facilities which would be required in time of serious national emergency; and that the solution lies in the commercial acquisition and operation of large numbers of long-range freight aircraft which would be instantly available, with crews and ground personnel, when needed.

It will not be amiss to furnish here modest but emphatic proof of the air freight carrier's ability to perform in an emergency. 
Late in June, I948, when the Russians blockaded Berlin to surface traffic and the Air Force threw every available airplane into what came to be known as "Operation Vittles," commercial air carriers were called upon to give logistical support, lifting engines and critical parts between this country and Frankfurt to keep the shuttle to Berlin going. First off the ground from Westover Field, Massachusetts, were two Seaboard airplanes to Frankfurt. Of the first twenty-five emergency flights, Seaboard made ten. On those ten flights -40 per cent of the total-it lifted 43 per cent of the tonnage; its average load exceeded the average of all other participants by 1,656 pounds.

In all, through December 3r, r948, Seaboard carried I,346,6rg pounds of critical military material over the North Atlantic on ro6 flights, and in addition shuttled I,258,800 pounds of commercial freight, vital to the airlift program, between Berlin and Frankfurt. Seaboard's over-ocean performance in this international emergency was not only far in excess of any single passenger airline, but was double the performance of all passenger airlines combined. Solely because its equipment, personnel, and methods of operation were instantly adaptable to the national defense demands, Seaboard carried the predominant share of military cargo.

This freight carrier performance should surprise no one. It did not surprise us. We were performing commercially in June, r948, exactly the kind of air transportation which the Air Force needed in a hurry; we had the equipment, the trained freight-flying crews, the expert loaders, the ground organization, and the flexibility to adapt ourselves instantly to the national defense need. The emergency was essentially no different than, for instance, that created by the Middle East cholera epidemic of two years ago. The World Health Organization at that time came to the infant Seaboard to lift 30,000 pounds of cholera vaccine to Cairo and Damascus. The vaccine was on its way eighteen hours after the conversations were opened. Neither national defense nor dread plague can wait while air transportation readjusts its thinking and thrashes about in an effort to adapt itself to operations completely foreign to its nature.

\section{VI}

Utilization of freight aircraft as instruments of world commerce is of vital significance to the economic, social, and political development of the world. Of far greater significance than mere speed is the creation of new markets, and the exchange of goods of all types and uses on a vast scale.

The fifteenth-century Portuguese traders, the Yankee Clipper ships, and the modern steam freighters have all made their contribution to shrinking the world, making its people known to one another, and developing commerce. The airplane is now ready. Properly developed and utilized, it will make the most inaccessible community the greatest port; it will create highways of the air to bring closer to realization the one world conception which is so necessary if civilization is to survive in the atomic age. Only the failure to see the possibilities and to adopt an intelligent air freight policy can thwart this ultima of transportation. 